\title{
THE ROLE OF LOCAL SELF-GOVERNMENT IN THE POLISH CONSTITUTIONAL SYSTEM
}

\begin{abstract}
Local government reform has been acknowledged to be one of the biggest successes of political transformation in Poland. Municipalities (gminy) gained strong powers and are now responsible for many public services of crucial importance to local communities. The districts (powiaty) and provinces (województwa) were also given important competences in the fields of public services and the responsibility for their development. Their autonomy is guarded by legal, institutional and financial guarantees and strong local leaders. The carefully designed institutional framework of local and regional government seemed to be permanent and durable, guaranteeing strong decentralization and providing local and provincial authorities with substantial decision-making powers and responsibilities for a vast majority of public services. Such a broad field for the functioning of the local government does not remain without interpretation problems. The consecutive central governments were finding common ground in their instrumental approach to local authorities' independence. It was convenient for the state to decentralize problems and challenges, while keeping control over finance and other resources, as well as looking for ways to increase supervisory powers over local government. Almost 30 years after the reintroduction of territorial self-government in Poland, it is expected to be well rooted in the constitutional system of Poland, but is it really so?
\end{abstract}

Keywords: Polish constitutional system, local and regional government.

*j.jakubek@uw.edu.pl 


\section{Introduction}

This paper analyses the local government's competences in Poland and provides a description of legislative framework and practical features of Polish local self-government in the context of its relations with the central government. It argues that the understanding of local government's decision-making competences needs to be wide, in order for the local government to achieve substantial autonomy and prevent growing recentralization tendencies.

The structure of the paper is as follows. In the first part, the concept of decentralization is analysed, with special focus on its understanding as the right of local communities to govern themselves (bottom-up approach),envisaged in the European Charter of Local Self-Government. Secondly, the history of local government restoration and reform in Poland is examined, as well as the legal framework and most important legal principles (enshrined in the 1997 Constitution and acts of parliament), to present the degree of local autonomy for the territorial units. Subsequently, the framework of self-government competences is analysed, as well as the practical aspects of local government's functioning in the context of constant tensions between recentralization and local autonomy.

The main argument of the paper is that the restoration of Polish local self-government in 1990 (and the deepening of decentralization in 1998) radically changed the system of the state and focused on building a framework of decision-making competences in accordance with the principle of subsidiarity. The foundations of the new administrative system proved to be permanent and were strengthened over the years, despite the inevitable corrections in the administrative division. The reform was intended to reconstruct civic awareness and establish new division of competences between the national and local government. These changes have undoubtedly modernized and improved the state, allowing for more effective governance and addressing new challenges. At the same time, they strengthened the processes of democratic control over the authorities, joint responsibility of the citizens for the state, and a stronger sense of participation in public affairs. Thanks to this reform, the Polish local government can be considered one of the most modern, especially in this part of Europe.

\section{The concept of decentralization}

The concepts of decentralization and local self-governance are inextricably linked. A non-transferable feature of local self-government is that it can only exist in a decentralized state in which citizens are granted the right to make their own decisions, taken in accordance with their interests. The local government is an emanation of the interests of these citizens - a public law corporation, that is, a public administration entity equipped with administrative authority. Its 
indispensable element is obligatory membership "by virtue of the law itself", clear rules of belonging (residence in the local government unit) and existence regardless of the number or change of members. This is the most comprehensive "micro-democracy", where the state transfers part of its administrative functions and confers legal personality; public administration tasks are performed by the citizens or their groups, equipped with specific competences and administrative powers. This is connected with the obligation to perform the delegated functions and the exclusive fulfilment of this obligation, additionally guaranteed by legal provisions that, apart from the designated scope of supervision, the state can not interfere with its activities. The principles of subsidiarity and decentralization are most fully implemented by the self-government.

Therefore, the local government has a significant and non-transferable characteristic; it means the right to settle the local community's affairs in accordance with their own interests and their identification. This right includes the assumption that a given community may behave differently in some matters than in others. Decentralization ensures that minorities' rights are recognized in their own decisions and choices, even if they are not always accurate. Activities under the local community's own tasks should not (and, under applicable law, cannot) be assessed in terms of purpose or reliability, because it interferes with local government autonomy and always means the application of criteria assessed for self-employed activities. Legality, therefore, remains the only criterion for supervision over the activities of local government as part of its own tasks ${ }^{1}$. Nowadays, decentralization does not depend only on independence in the "imperious" sphe$\mathrm{re}$, but it is the basis for independent management of public affairs primarily in economic terms, in a network system, not in hierarchy, by achieving social and economic benefits on a local or regional scale. Self-governance is implemented by acting for the development of a given local government unit, organizing the delivery of public services, as well as cooperation and competition with other local governments and participation in supra-local and supra-regional markets (Kulesza, 2009: 11).

\section{Restoration and reform of Polish local government}

The restoration of Polish local self-government in 1990 (and the deepening of decentralization in 1998) radically changed the system of the state, focusing on building a framework in accordance with the principle of subsidiarity. Between the assumptions of the functioning of local authorities in the Polish People's Re-

1 However, the decision-making autonomy of the local government is not always unconditional or uncontroversial. Problems may arise, for example, in standardized public services, such as education or health care. The decentralization of public authority cannot be in contradiction with the constitutionally guaranteed equality of citizens in access to public services. 
public (PRL) and the Third Republic of Poland (after 1989) there was an evident dichotomy, which concerned not only the issue of organization and functioning of the state, but above all the distribution of public authority at the national and local level. The complexity, hierarchical multilevel construction, intersection of various divisions of special administrations and strongly centralized administration were inherited after the socialist system, which was based on ministerial (vertical) connections, both in the decision-making and financial aspects. After political changes and the termination of the communist party's leading role, the premise of centralism in government has been eliminated, and it has become an obstacle in the construction of the administration of a democratic state.

The restitution of self-governing local government was one of the necessary conditions for the shift to the democratic system in Poland and building a civil society. Without independent local government (that is, transferring the real part of public authority to the level of local communities) and without social involvement, it would be impossible to develop the country as a result of citizens' work. In the PRL, cutting off local communities from decision-making blocked the initiatives and activities of people. Only the creation of appropriate conditions for free action of residents of municipalities (gmina) and districts (powiat) gave the opportunity for local authorities to play a significant role in economic development (Regulski, 2010: 2).

The year 1990 undoubtedly had the most important, even revolutionary, significance for the Polish administration, in which the local self-government was restored after 40 years of non-existence. The overriding objective of this reform was to hand over tasks to local government and cut off the current management of local affairs from the national level. The principle of uniform state authority and ownership was broken, and much better conditions for the development of local communities were created, which facilitated the processes of their empowerment. Regional competition has been strengthened, while providing better instruments for management of public services.

Another important aspect of decentralisation was the very narrow supervision from the central government and the control of independent administrative courts. The judicial form of supervision was supposed to prevent any bias in the management of, sometimes inevitable, conflict between the central and local government bodies. The administrative courts were also supposed to serve as impartial guardians of local government's competences.

After restoring local self-government, a significant strengthening of the state's capacity for efficient functioning was expected. It was a necessary systemic change, as without it there was a threat of maintaining a system programmed for state centralism and a lack of democratic control over the decision-making 
processes in the administration. In 1998, another stage of the decentralization reform was undertaken, transferring to the Polish local government yet another large degree of shared responsibility for governing the state and competences previously reserved for government administration. An important assumption was the lack of hierarchical subordination between individual local government units and the condition that citizens should have equal access to local administration bodies and influence on their institutions. The reform was also intended to enforce public finance reform, with far-reaching decentralization of planning and settlement of public expenditure ${ }^{2}$.

Democratization of the system involved the introduction on the next two levels of self-government bodies being elected by universal and direct elections. The district council (radapowiatu) has acquired specific competences: to decide on local law, to choose and dismiss the management board, to determine the direction of the executive's activity, to adopt the budget, and to adopt resolutions on the county property matters. The regional assembly (sejmik województwa) was granted the power to adopt a regional development strategy, spatial development plan, regional budget, appointment and dismissal of the management board (executive), and adoption of resolutions on property matters of the region/ voivodship.

In the adopted model, the council did not have only an acceptance role; through the majority of votes, it was to provide a "political umbrella" to the executive, which was competent mainly to execute council resolutions, prepare draft resolutions, manage property and implement the budget. Having a mandate coming from general and direct elections, the council had a position to authenticate and account for the activities of the collective management board (executive). In the next stage of the reform, involving the introduction of direct elections of one-person executive bodies of the commune, part of this responsibility was delegated to the voters, thus strengthening the position of the municipal executive. The head of municipality (city mayor/president) as a single-person body has more possibilities of action, especially when it has a direct election mandate and does not necessarily share the political system dominant in the council, and has its own significant competence. The choice by the council of the collegial executive, on the other hand, means that the political factor depends to a certain extent on it, making it more susceptible to political pressure.

The continuation of local government reforms was also closely aligned with Poland's efforts to join the European Union: preparing for new challenges in the field of multi-level public management, absorption of European funds, partici-

2 However, this result has not been fully achieved (Kieżun 2004, Chojna-Duch 2003). 
pation in European programsand even decision-making on European matters, setting a strict division between tasks of the national and local government.

The main objective of the reform was undoubtedly the decentralization of state power, as well as the continuation of changes initiated in 1989 and 1990. To achieve this, the competence between the central and local government had to be re-established, and local responsibilities defined together with equipping the local units with legal and financial means to address them. Another goal was to organize the territorial structure of the state in the form of a more transparent and understandable division and rationalization of administrative structures. An important consequence of introducing two successive levels of local government was that it generated the emergence of another level, thus establishing local elites to lead further democratization of the country and the combat against the legacy of the PRL. The mechanisms of local democracy gained a strong legal instrument in the form of civic control of local government authorities. An important consequence of the reform was also the assumed reconstruction of the public finance system and an impulse for more effective financial management at all levels of the administration.

In a comparative perspective, it is even clearer that local government reforms were necessary. There were no alternative ways of modernization in Central and Eastern Europe; no such in-depth reforms were implemented in other postcommunist countries. The most far-reaching changes took place in Poland. In most other countries in the region, only "nomenclature" changes were introduced (e.g. by renaming the soviets into city councils); free elections were added to the old system but they were carried out under the conditions of a single, centralized state machine. In most Central and Eastern European countries, therefore, the local government reform consisted of only two modifications: carrying out free municipal elections, and changing the naming of local authorities; however, no specific powers were delegated to the local government. The difference between the real and the apparent reform can be judged by looking at the effects: the introduction of democracy without reconstruction of the administration and guaranteeing independence for local government units did not leave any of the substantive competences to the local level.

\section{Constitutional framework of Polish local government}

The work on the Polish Constitution of 1997 lasted since the early 1990s and took place with full awareness of the fundamental importance of the principle of subsidiarity, decentralization and independence of local government. The 
interim so-called "Little Constitution" 3 of 1992 defined the local government as "the basic form of organization of local public life" (Article 70 paragraph 1) and granted territorial units legal identity and competences in public matters (Izdebski, 2014: 80). Earlier, in the Constitution of 22 July 1952, the title of Chapter 6 was changed from "Regional authorities and state administration" to "Local government", with the first provision of this chapter situating local government as the basic form of public life.

The Constitution of 2 April 1997 devotes the entire Chapter VII (Articles 163172) to the local government, in addition to Articles 15 and 16 which set out fundamental legal basis for the functioning of the local government, declaring the principle of decentralization of public authority, taking into account social, economic or cultural ties in territorial division, creating ex lege of the local government community by the population of the territorial units. Another important provision is that the local government participates in the exercise of public authority, and performs public tasks on its own behalf and on its own responsibility (Article16 paragraph 2). The Constitution includes, first of all, the foundations of the political system on which the system was based after 1989:

- the principle of a democratic state of law,

- the principle of political pluralism,

- the principle of decentralization,

- the principle of subsidiarity,

- the principle of autonomy of the municipality (gmina),

- presumption of competence for the municipality (gmina),

- the principle of legalism.

In the new administration structure, the municipality, constitutionally recognized as the basic unit of the territorial division of the country, had a legitimate constitutionally leading position in relation to other units of territorial division; it served the presumption of tasks and competences not reserved for other local government units. The districts and the self-governmental voivodships (provinces) were to exercise competences reserved for them in statutes. In Chapter VII, the Constitution clarifies the basic character of the municipality (Article 164 par.1) and the presumption of responsibilities (Article 164 par. 3), at least the two-tier structure of the local government (Article 164 par. 2). It accepts the existence of regional self-government as well as direct elections to all bodies

3 Constitutional Act on mutual relations between the legislative and executive power of the Republic of Poland and on local self-government of October 17, 1992, Dz.U. 1992 No. 84 item 426. 
constituting the local government. The provision of Article 163 contains an important presumption of competence in the performance of public tasks for the benefit of local government. Article 165 protects the property rights and legal personality of local government units, while Article 166 emphasizes the role of local government in satisfying the needs of the local community. Article 170 provides an additional guarantee on the legal standing to the community of inhabitants as active legal subjects, granting them the subjective rights to decide by way of a referendum, while the limits of supervision over the local government are clarified in Article 171.

The sum of the provisions of the Constitution (and the earlier Local Government $\left.\mathrm{Act}^{4}\right)$ meant a radical break with the tradition of the PRL's "national councils" and opened the door for further decentralization. Emphasizing the separate legal identity, performing public tasks "on own behalf and on its own responsibility" (Article 16 paragraph 2) and limiting the administrative duality to the regional level (province, voivodship - województwo) emphasize the role of selfgovernance in the exercise of public authority. An additional significant feature is the lack of hierarchical subordination of local government units, each of which is a fully independent local community with a democratic structure of internal organization, separated from other institutions in order to decentralize the implementation of a substantial part of local public administration tasks, with the right to use the legal forms of public administration authority.

\section{Distribution of competences}

An administrative system is always adapting to new demands, and a continuous rearrangement of competences seems to be the answer to changing demands and requirements on all levels of governance (central, regional and local). The first important issue when it comes to the framework of local government competences is designing the optimal size of territorial units.

In recent studies, three aspects have been indicated as the most important ones when discussing the effectiveness of the optimal size of territorial units in territorial management. The first aspect is the ability of the local government units to provide services; there are studies suggesting that smaller units cannot cope with the performance of certain tasks (Swianiewicz, 2014).The second aspect concerns the costs ("the economy of scale"), regarding whether the performance of a larger self-government unit is more efficient than the performance of a small one. The third problem to be addressed is the functioning of local democracy. Here, the views are also divided, including some opinions that small self-government units mean more trust and closer contact between the citizens

4 The Local Government Act of 8th March 1990 
and local authorities. Others argue that smaller size could affect democracy, as the competition between candidates is limited, and it is counterproductive to the networking of civic organizations, leading to tendencies to form closed elite groups without alternative options (Swianiewicz et al., 2016).

As already mentioned, the distribution of competences between the levels of government is not a definite issueand, from time to time,it can (and should) be the subject of critical evaluation. When it comes to the competences of the Polish local and regional governments, they were mostly assigned in 1990 (to municipalities) and 1998 (to districts and provinces). These were the years of the actual re-establishment of the local government and, then, adding two tiers at the local and regional level. Since then, the laws have not been changed when it comes to the tasks and competences, even though the external circumstances (both technical and political) have changed. On the other hand though, the central government has been very active in hollowing out the local and regional government competences, not by changing the laws but rather by centralising the financing of certain public services or changing the structure of local government's income (e.g. by cutting taxes that are an important source for the local budgets). Therefore, it can be stated that the current framework of competences does not always fully correspond to the real challenges of local and regional self-government units.

The competences of Polish municipalities include:

- Spatial planning (local planning; water and supply sewage treatment; maintenance of landfills);

- Waste management;

- Real estate management;

- Public areas (including cemeteries);

- Transport (local roads; local public transport);

- Public order and safety,

- Telecommunications;

- Environment (protection; zoning and local environmental protection);

- Electricity, gas and heat supply;

- Health (Primary healthcare services);

- Social welfare;

- Family support and foster care system;

- Maintenance of municipal buildings and public facilities;

- Market places; 
- Housing;

- Culture (promotion, management of municipal libraries and other cultural institutions, monument protection);

- $\quad$ Sports (promotion); and

- $\quad$ Education (kindergartens; elementary education).

Polish districts are responsible for local issues which cannot be granted to the municipalities. In particular, the competences of Polish districts are as follows:

- $\quad$ Sports and tourism;

- Geodesy and cartography;

- Real estate management, architecture and buildings administration;

- Water resources management;

- Agriculture, forestry and inland fisheries;

- Cooperation with NGOs;

- Education (secondary education, i.e. post-elementary schools, vocational and special schools);

- Environmental protection;

- Health (general responsibility for the operation of the public health service institutions);

- $\quad$ Consumer protection;

- Social welfare (services that extend beyond the municipalities' boundaries; support to the disabled; maintenance of county facilities and public utilities);

- Child protection (running tutelary and educational facilities, including orphanages);

- Employment (district labour office; fight against unemployment);

- Transport (road building and maintenance at the district level);

- Telecommunications;

- Defence;

- Civil protection;

- Flood protection;

- Fire protection;

- Maintenance of public order and collective security; and

- Support to cultural institutions (culture and monuments). 
The competences of Polish provinces are as follows:

- Economic development;

- Employment and labour market policy (fight against unemployment);

- Protection of employees claims in case of employer insolvency;

- Transport (regional roads management and transport management);

- Telecommunications;

- Health (health promotion, specialised health services, medical emergency and ambulance services);

- Regional cultural institutions;

- Planning (spatial development; water management, land amelioration; maintenance of hydro-installations);

- Rural areas modernisation;

- Education (running post-secondary schools, some secondary schools and vocational schools, teacher training colleges, regional libraries; initiating the establishment and financing of higher education);

- Social welfare;

- Sports and tourism;

- Consumer rights protection;

- Defence;

- Maintenance of public order;

- Environmental protection; and

- Pro-familial policy (including family support and foster care system).

Based on: Local Government Act / Law on Municipal Self-Government from 8 March 1990, Law on District Self-Government from 5 June 1998, Law on Provincial Self-Government from 5 June 1998

As it is known from the conducted studies, the mutually connected systems of territorial self-government and administration have also in-built tendencies to become obsolete (Dostal and Saey, 2000: 2). The structure and functioning of the territorial system require more or less continual reform, and achieved reforms appear to provide more of a variable than uniform results. The framework of local and provincial competences in Poland seems to be in urgent need of this kind of reform and adjustment both in terms of the new challenges of public service provision and in defending the concept of local community control over the "substantial share of public affairs under their own responsibility and in the 
interests of the local population" (European Charter of Local Self-Government, Art.3).

\section{The functioning of the Polish local government in practice}

The functioning of the Polish local government system in practice is not problemfree, nor spared of specific "local government authority diseases". The most important of them include the sometimes apparent character of representative democracy (weakness of councils, especially in relations with the executive of the municipality), deficiency of transparency and openness of local government bodies, as well as quite an archaic formula of civic participation and resistance of local elites against wider admission of residents to decide on local matters. These problems should be discussed and solutions should be sought; however, toutes proportions gardées, it must be remembered first of all that the restoration of the local government has modernized and improved the Polish state, allowing for more efficient governance and meeting new civilization challenges, strengthened democratic control over the authorities and joint responsibility of citizens for the state, and triggered a stronger sense of participation in public affairs.

The decentralization of public authority primarily allowed the state to give up the responsibility for the current management of public affairs, transferring these competences to the local governments ${ }^{5}$. Only then was it possible to complete the reconstruction of the state's political and administrative centre, with emphasis on handling strategic matters. As a result, a clearer division of public authority functions was introduced between the three main segments of the state system: the local government (in municipalities and districts), responsible for meeting the collective needs of local communities; the regional self-government (in provinces), responsible for regional development policy; and the state government and their administration (central and local), responsible for matters of a national nature, as well as for compliance with law and supervision over the local government (province governors/voivods -wojewodowie). The reform did not only change the administrative division of the country but also led to the reconstruction of the administration and a more effective division of competences and responsibilities.

The functioning of the local government can be considered one of the greatest successes of the Polish transformation. However, the practice of government administration indicates an instrumental approach to local governments, while decentralization often means transferring tasks and problems without accom-

5 Local government controls over a third of all public expenditures and a remarkable $70 \%$ of public investment, delivering the goods, transforming environmental infrastructure, transport systems, urban spaces and public schools (Levitas 2017, Sześciło et al. 2019). 
panying financial resources 6 . As a result of decentralization reforms, the central administration has lost a large part of its competences and impact on current public affairs. New tensions between the national and the local government were born and, in the long-term perspective, there were growing recentralization tendencies on the national level. Initially, the problem concerned in particular the issue of management and distribution of EU funds allocated for regional development (regional funds), in which the central authority from the beginning played a major role (Kulesza, 2000:195).

The recentralization tendencies, which have been visible for a long time, have been intensifying, gradually depriving the local covernmentof control over successive areas of tasks and tightening supervision over the local government. Further actions that limit the ability of local governments to act effectively may even bring it down to the role of the contractor of the centre's commands, deprived of political independence and its own competences. After 1999, many changes were introduced that were unfavourable for local governments, including issues related to participation in income taxes (PIT and CIT), tightening central control over resources in the health care system, disregarding the legal standing of local governments when changing communal boundaries, attempting to over-extend the competences of supervisory authorities over the local government, or failed approaches to the introduction of metropolitan governance. In recent years, there has been a centralist acceleration, visible both in the form of educational reform, centralization of environmental protection funds and environmental protection administration, planned centralization of employment agencies, attempts to radically expand supervisory competences of the Regional Audit Chambers (RIO), as well as in the central form of the housing program "Mieszkanie+", entering the field taken so far by local governments within the framework of municipal construction. If the direction of change is maintained, in a short time the local government could become a structure devoid of real independence and own competence, which enableits independent functioning. Without the formal winding-up of local government, it may turn out that the structure of public authority is inevitably heading towards the centre, taking up, in a bit, the competences previously arranged in a logical manner at particular levels of local government units.

6 This is evident, for example, in education, where funds transferred to the local government in the form of educational subsidies are not sufficient, and most municipalities must pay extra to maintain schools drawing on their own resources, at the expense of other tasks. See: http://www.wspolnota.org.pl/rankingi/ranking-oswiatowy/subwencja-oswiatowa/ 


\section{Conclusions}

The Polish local government is the main functional component of a broad system of public administration, responsible for the vast majority of day-to-day public services. Decentralization served both as a tool for dismantling the communist state and as the foundation of a broader state-building strategy, with purposeful division of powers between the central and the local government. Poland avoided the fragmentation and apparent character of reforms conducted in most other Central European countries, providing local authorities with democratic mandate from popular vote, legal identities, independent budgets, property rights, control over their personnel and substantive competences in the field of public services. Independence of the local government is seen both as public administration reform and democratic empowerment in order to build a stronger state. On the other hand, Poland's success in restoring the local government system seems to have been diminished by creeping recentralisation and continuous efforts from the central government to conform the local authorities to a wider control and dependence.

An alternative to limiting the local government and the growing control of central government may be a stronger empowerment of local communities, which not only observe and oversee the actions of local authorities but have real instruments of co-deciding and accounting for local government bodies for all shortcomings or failures. Therefore, the most important evaluating role in relation to the actions of local authorities should belong to the inhabitants of local government units.

The only way to build a genuine local community, as opposed to top-down/ enforced local cooperation, is making this project attractive to the people. Recentralization is not a solution to the current problems of the local government, but rather a recipe for deepening the existing problems and creating new ones, related to the deficiencies of effectiveness of the central government.

\section{References}

Chojna-Duch E. (2003). Cele i skuteczność reformy administracji publicznej w latach 1999/2001. Aspekty finansowo-prawne oraz funkcjonowanie, in: A. Piekara (ed.), Cele i skuteczność reformy administracji publicznej w RP w latach 1999-2001, LexisNexis, Warszawa.

CBOS (2000). Cztery reformy w opinii społecznej: poinformowanie i ocena. Komunikat z badań Centrum Badania Opinii Społecznej, Warszawa, accesible online at: https://www.cbos.pl/SPISKOM.POL/2000/K_094_00.PDF 
Dostal P., Saey P. (2000). Geography, public administration and governance, Belgeo, 1-2-3-4|2000, [Online] since 12 July 2015, available at URL: http:// journals.openedition.org/belgeo/13908; DOI: 10.4000/belgeo.13908, accessed on 19 April 2019.

Gadomska B. (2003). Opinia publiczna wobec reform decentralizacyjnych, in: A. Piekara (ed.), Cele i skuteczność reformy administracji publicznej w RP w latach 1999-2001,UW, Warszawa.

Izdebski H (2014). Samorząd terytorialny. Podstawy ustroju i działalności, LexisNexis, Warszawa.

Izdebski H. (2015).Domniemanie zadań samorządu terytorialnego i domniemanie zadań gminy w obrębie samorządu terytorialnego - klauzule generalne dotyczące zadań samorządu, in: Samorząd Terytorialny Journal 1-2/2015.

Jagoda J.(2011). Sądowa ochrona samodzielności jednostek samorzq̨du terytorialnego, Wolters Kluwer, Warszawa.

Jakubek J. (2010). Reforma administracji publicznej 1998 r.: z perspektywy minionej dekady, [Public administration reform of 1998 - the perspective of past decade], in: Społeczeństwo i Polityka,Journalnr 1/2010, nr 1, s. 95-113.

Jakubek-Lalik J. (2019). Decentralizacja czy recentralizacja? Kilka uwag o regulacji konstytucyjnej i praktyce funkcjonowania samorządu terytorialnego w Polsce, [Decentralizationorrecentralization? Remarks on the constitutional basis and practice of local self-government functioning in Poland] in: Decentralizacja i centralizacjaadministracji - wspótczesnywymiar $w$ teoriiipraktyce, [Decentralization and centralization of administration - the contemporary dimension in theory and practice]; eds. B. Jaworska-Dębska, E. Olejniczak-Szałowska, R. Budzisz; Wyd. Wolters Kluwer, Warszawa-Łódź 2019.

Jastrzębska M. (2011). Fakultatywne zadania własne gminy w świetle obowiązujących regulacji prawnych, in: "Finanse Komunalne" Journalnr 1-2/2011.

Kociński C. (2007).Normy domniemania w prawie samorządu terytorialnego, in: "Samorzad Terytorialny" Journalnr 5/2007.

Kornberger-Sokołowska E. (2013). Zasada adekwatności w systemie finansów samorządu terytorialnego w Polsce,LexisNexis,Warszawa.

Kieżun W. (2004). Struktury i kierunki zarządzania państwem, in: Kieżun W. i Kubin J. (ed.), Dobre państwo, Wydawnictwo WSPiZ, Warszawa.

Kulesza M. (2009). Ile decentralizacji w centralizacji, czyli o nawykach uczonych administratywistów, in: „Samorząd Terytorialny”Journalnr 12/2009. 
Kulesza M. (2000). Słowo końcowe, Pełnomocnik i polityka, in: J. Milewicz, A. Wołek, Reformatorzy i politycy. Gra o reformę ustrojowa 1998 roku widziana oczami jej aktorów, wyd.1 DANTE, Wyższa Szkoła Biznesu - National-Louis University, Nowy Sącz-Warszawa 2000.

Ladner A., Keuffer N., Baldersheim H. (2016). Measuring local autonomy in 39 countries (1990-2014), Regional and Federal Studies, Taylor and Francis, accessible online: https://www.tandfonline.com/doi/abs/10.1080/13597566.2016. 1214911

Levitas A. (2017).Local Government Reform as State Building: What the Polish Case Says About „Decentralization”, St Comp Int Dev 2017 52:23-44.

Moreno A.M.(ed.) (2012).Local government in the member states of the European Union: a comparative legal perspective, National Institute of Public Administration, Madrid, Spain

Parrado S. (2005). Assigning Competences and Functions to Local Self-Government in Four EU Member States: a Comparative Review, Paper prepared for Sigma, Madrid 2005

Regulski J. (2010). Samorząd a model państwa, in: Infosnr 10/2010, Biuro Analiz Sejmowych, 20 May 2010, Warszawa.

Salachna J.M. (2011). Granice swobody decyzyjnej/legislacyjnej samorządu terytorialnego w zakresie finansowania zadań, in: "Finanse Komunalne" Journal nr. 1-2/2011.

Stein R.M. (1990).Urban Alternatives: Public and Private Markets in the Provision of Local Services, University of Pittsburgh Press, Pittsburgh.

Swianiewicz P. (2014). An empirical typology of local government systems in Eastern Europe, in: Local Government Studies, 40(2), 292-311, Taylor \& Francis, accessible online:

https://www.tandfonline.com/doi/full/10.1080/03003930.2013.807807

Swianiewicz P., Gendźwiłł A., Łukomska J., KurniewiczA.,(2016) Wielkość gmin i powiatów a sprawność ich funkcjonowania: hipotezy wielkoludów i liliputów, Scholar, Warszawa.

Sześciło D., Bendyk E., Jakubek-Lalik J., Jakubowski P., Kłucińska P., Łapszyński R., Przedańska J., Smolar A., Szwast M., Wilk B., Zakroczymski S. (2019), Polska samorzqdów. Silna demokracja, skuteczne państwo, Fundacja Batorego, Warszawa 
Węgrzyn-Skarbek M. (2009). Zadania samorządu terytorialnego w świetle ustrojowych ustaw samorządowych a zasada pomocniczości, in: "Administracja: Teoria, Dydaktyka, Praktyka" Journal nr. 2/2009,

Zalewski A. (2007). Nowe zarządzanie publiczne w polskim samorzadzie terytorialnym, Szkoła Główna Handlowa, Warszawa.

\section{Dr Jowanka Jakubek-Lalik,}

Придружени професор, Катедра за управно право,

Департман за правно-административне науке,

Факултет права и администрације, Универзитет у Варшави,

Република Пољска

\section{УЛОГА ЛОКАЛНЕ САМОУПРАВЕ У ПОЉСКОМ УСТАВНОМ СИСТЕМУ}

\section{Резиме}

Реформа локалне управе призната је као један од највећих успеха политичке трансформације у Пољској. Општине (gтіпу) су добиле важна овлашћења у области јавних услуга од кључног значаја за живот локалне заједнице. Окрузи (powiaty) и покрајине (województwa) такође имају важне надлежности у области јавних услуга и одговорност за њихов развој. Њихову аутономију чувају правне, институционалне и финансијске гаранције и јаки локални лидери. Пажљиво осмишљен институционални оквир локалне и регионалне власти деловао је као постојан и отпоран систем, који гарантује снажну децентрализацију и даје локалним и покрајинским властима значајна овлашћења и одговорност у доношењу одлука у погледу већине јавних служби. Међутим, широко поље надлежности локалне самоуправе донело је многе проблеме у погледу тумачењ а прописа. Централни органи власти су успевали да пронађу адекватан инструментални приступ и очувају независност локалних власти. Држави је одговарало да децентрализује проблеме и изазове, али да задржи контролу над финансијама и другим ресурсима, као и да налази начине да повећа надзорна овлашћења над локалном управом. Скоро 30 година након поновног увођења територијалне самоуправе у Пољској, локална самоуправа би требало да буде добро укорењена у уставном систему Пољске, али да ли заиста тако?

Кључне речи: пољски уставни систем, локална и регионална самоуправа. 
